\title{
Evaluation of biomedical waste management in primary health care centres in Saudi Arabia: a knowledge, attitudes and practices study
}

L. Kalyan V. Reddy ${ }^{7}$ and Fares Al Shammari ${ }^{1}$

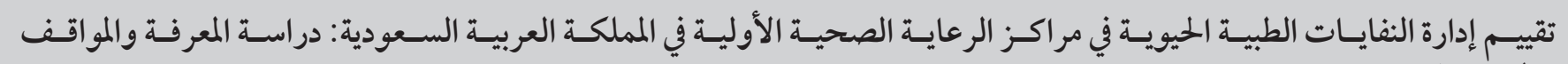

$$
\begin{aligned}
& \text { والملارراسـات } \\
& \text { كايلان فيسواناث ريدي، فارس الشمري }
\end{aligned}
$$

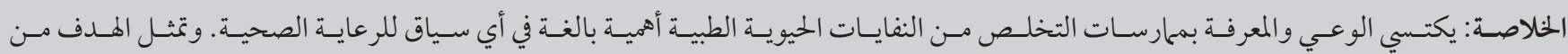

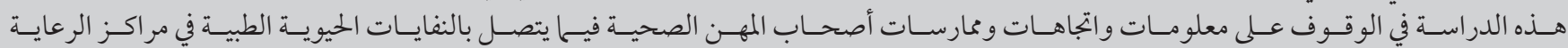

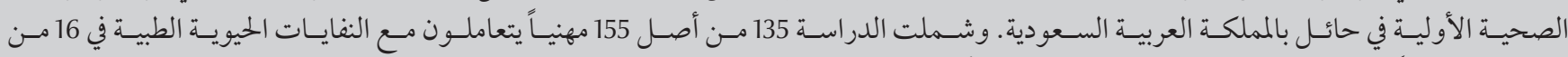



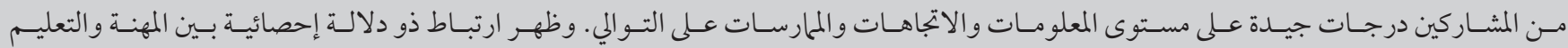

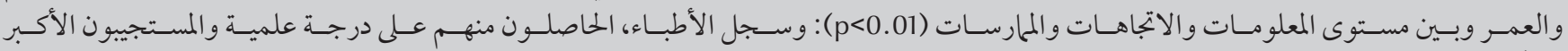

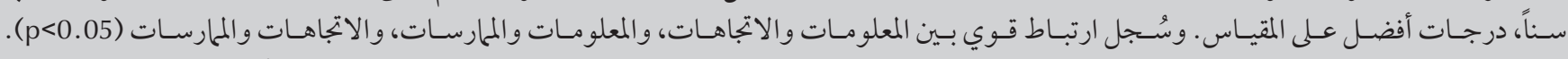

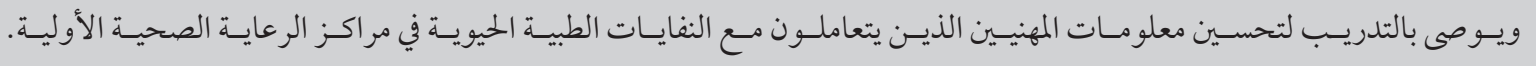

ABSTRACT Awareness and knowledge of biomedical waste practices is very important for any health care setting. This study aimed to determine the knowledge, attitudes and practices (KAP) about biomedical waste among health professionals in primary health care centres in Hail City, Saudi Arabia. The study included 135 of 155 professionals who dealt with biomedical waste from 16 out of 26 primary health care centres. Data were collected using a structured questionnaire. Overall 54.8\%, 48.9\% and 49.6\% of the participants had good knowledge, attitudes and practices scores respectively. Profession, education and age were significantly associated with KAP level $(P<0.01)$ : doctors, those with a degree and older respondents had better KAP scores. There was a strong correlation between knowledge and attitudes, knowledge and practices, and attitudes and practices $(P<0.05)$. Training is recommended to enhance the knowledge of the professionals dealing with biomedical waste in the primary health care centres.

Évaluation de la gestion des déchets biomédicaux dans les centres de soins de santé primaires en Arabie saoudite : étude sur les connaissances, attitudes et pratiques

RÉSUMÉ la prise de conscience et la connaissance des pratiques concernant les déchets biomédicaux sont très importantes pour tous les milieux de soins. La présente étude avait pour objectif de déterminer les connaissances, attitudes et pratiques concernant les déchets biomédicaux parmi les professionnels de la santé dans les centres de soins de santé primaires à Hail (Arabie saoudite). L'étude incluait 135 des 155 professionnels de la santé qui prenaient en charge des déchets biomédicaux dans 16 centres de soins de santé primaires sur 26. Les données ont été collectées au moyen d'un questionnaire structuré. Au total, $54,8 \%, 48,9 \%$ et 49,6 \% des participants avaient des bons scores pour les connaissances, attitudes et pratiques respectivement. L'occupation, l'éducation et l'âge étaient significativement associés au niveau des connaissances, attitudes et pratiques $(p<0,01)$ : les médecins, les personnes diplômées et les répondants âgés avaient des meilleurs scores pour les connaissances, attitudes et pratiques. Il y avait une forte corrélation entre les connaissances et les attitudes, entre les connaissances et les pratiques ainsi qu'entre les attitudes et les pratiques $(p<0,05)$. Une formation est recommandée afin de promouvoir les connaissances des professionnels qui prennent en charge des déchets biomédicaux dans les centres de soins de santé primaires.

'Department of Health Services Administration, College of Public Health and Health Informatics, University of Hail, Hail, Saudi Arabia. (Correspondence to: L. Kalyan V. Reddy: kalyan2060@gmail.com).

Received: 09/10/16; accepted: 07/12/16 


\section{Introduction}

Biomedical waste poses a high risk not only to doctors, nurses, technicians and ancillary staff working in hospitals and health centres but also to patients, visitors, the community and the environment because of arbitrary management of such waste (1). A study conducted in a tertiary care hospital in Rajkot, India concluded that the lack of proper and complete knowledge about biomedical waste management affected practices of appropriate waste disposal (2). Another study concluded that there was a need to improve the knowledge, skills and competency of hospital staff by providing advanced facilities and on-job training in order to develop standard operating procedures for biomedical waste management (3). The lack of knowledge among nurses and multipurpose workers regarding segregation and colour coding of waste was highlighted in other research (4).

A lack of good knowledge, attitudes and practices (KAP) regarding safe segregation, collection, storage, treatment, transport and disposal of biomedical waste is one of the main reasons for the poor management of biomedical waste. In this context, we sought to evaluate the awareness of biomedical waste management among health professionals working in primary health care (PHC) centres in Hail City, Saudi Arabia. The specific objective of the study was to assess the KAP of the doctors, nurses and other professions (laboratory technicians and PHC managers) who dealt with biomedical waste and its management in the PHC centres.

\section{Methods}

This study was conducted from June to December 2015. A non-probability purposive sampling method was used to select professionals working in PHC centres in Hail City who dealt with biomedical waste and its management.
There are 26 PHCs in Hail City, of which 16 were selected based on simple random sampling. Of the 155 professionals working with biomedical waste and its management in the 16 PHCs, 135 agreed to participate $(87 \%$ response rate).

Data were collected using a structured self-completed questionnaire developed by the investigators. Information was collected on: sociodemographic characteristics of the respondents; their KAP of biomedical waste; and suggested ways to improve biomedical waste practices in their PHC centre. The questionnaire was in both English and Arabic. Cronbach alpha was used to assess reliability (0.620).

For each KAP component, there were 10 items; if the respondent's score was 6 or more, he/she was categorized as having good knowledge, attitudes or practices and if the respondent's score was less than 6 , he/she was categorized as having poor knowledge, attitudes or practices.

The data were coded and entered in SPSS, version 21.0 for analysis. The chi-squared test was used for to evaluate differences according to the variables of interest (sex, age, education and profession).

Approval to conduct the study was obtained from the Ministry of Health, Saudi Arabia (Log number 15-471E) and approval to conduct training and data collection was obtained from the Ministry of Health in Hail City. Informed consent was obtained from all the participants.

\section{Results}

Socioeconomic characteristics of the respondents: $51.1 \%$ of the respondents were women. Out of the 135 respondents, $54.8 \%$ were aged $26-35$ years, $24.4 \%$ were $36-45$ years, $17.8 \%$ were $46-55$ years and $3 \%$ were 56 years and over. With regard to educational qualifications, $54.1 \%$ were degree holders, while $45.9 \%$ had diploma certificates. With regard to profession, $51.9 \%$ were doctors and $48.1 \%$ were other health professionals such as nurses, laboratory technicians and PHC managers.

Table 1 shows the level of overall knowledge of the respondents and their knowledge according to demographic characteristic. Overall, 54.8\% of the respondents were categorized as having good knowledge about biomedical waste management. The mean (standard deviation) score for overall knowledge was 3.89 (0.50).

There were statistically significant differences between those with good knowledge compared with poor knowledge related to biomedical waste management according to profession, education and age $(P<0.001)$. The results showed that $91.4 \%$ of the doctors had good knowledge of biomedical waste management compared with only $15.4 \%$ of the other professions (nurses, PHC managers and laboratory technicians); $91.9 \%$ of those with a degree had good knowledge compared with only $4.8 \%$ of those with a diploma; and over $90 \%$ of professionals aged 46 years and older had good knowledge compared with less than $52 \%$ of those under 46 years. There was no statistically significant difference in good knowledge according to sex.

Table 2 shows the overall attitudes of the respondents and their attitudes according to demographic characteristic. Overall, $48.9 \%$ of the respondents were categorized as having good attitudes about biomedical waste management. The mean (standard deviation) score for overall attitude was $3.84(0.50)$.

There were statistically significant differences between those with good compared with poor attitudes related to biomedical waste management according to profession, education and age $(P<0.001,<0.001$ and 0.004 respectively). The results showed that $84.3 \%$ of the doctors had good attitudes towards biomedical waste management 


\begin{tabular}{|c|c|c|c|c|c|}
\hline \multirow[t]{2}{*}{ Demographic characteristic } & \multicolumn{2}{|c|}{ Good knowledge $^{1}$} & \multicolumn{2}{|c|}{ Poor knowledge ${ }^{1}$} & \multirow[t]{2}{*}{$P$-value } \\
\hline & No. & $\%$ & No. & $\%$ & \\
\hline Sex & & & & & 0.095 \\
\hline Male & 41 & 62.1 & 25 & 37.9 & \\
\hline Female & 33 & 47.8 & 36 & 52.2 & \\
\hline Age (years) & & & & & 0.001 \\
\hline $26-35$ & 31 & 41.9 & 43 & 58.1 & \\
\hline $36-45$ & 17 & 51.5 & 16 & 48.5 & \\
\hline $46-55$ & 22 & 91.7 & 2 & 8.3 & \\
\hline$\geq 56$ & 4 & 100.0 & 0 & 0 & \\
\hline Education $^{2}$ & & & & & 0.001 \\
\hline Degree & 67 & 91.9 & 6 & 8.1 & \\
\hline Diploma & 3 & 4.8 & 59 & 95.2 & \\
\hline Profession & & & & & 0.001 \\
\hline Doctor & 64 & 91.4 & 6 & 8.6 & \\
\hline Other professions ${ }^{3}$ & 10 & 15.4 & 55 & 84.6 & \\
\hline Total & 74 & 54.8 & 61 & 45.2 & \\
\hline
\end{tabular}

${ }^{\prime}$ Good knowledge: respondent score $\geq 6$ out of 10 questions; poor knowledge: respondent score < 6 out of 10 .

${ }^{2}$ Degree: respondents working in PHC with 3-4 years of tertiary education; Diploma: respondents working in PHC with 1-2 years post high-school education.

${ }^{3}$ Other professions were: nurses, laboratory technicians and primary health care (PHC) managers.

compared with only $10.8 \%$ of the other professions (nurses, PHC managers and laboratory technicians); $86.3 \%$ of those with a degree had good attitudes compared with only $4.8 \%$ of those with a diploma; and over $75 \%$ of professionals aged 46 years and older had good attitudes compared with less than $43 \%$ of those under 46 years. There was no statistically significant difference in good attitudes according to sex.

Table 3 shows the overall practices of the respondents and their practices, according to demographic characteristic.

\begin{tabular}{|c|c|c|c|c|c|}
\hline \multirow[t]{2}{*}{ Demographic characteristic } & \multicolumn{2}{|c|}{ Good attitudes $^{1}$} & \multicolumn{2}{|c|}{ Poor attitudes ${ }^{1}$} & \multirow[t]{2}{*}{$P$-value } \\
\hline & No. & $\%$ & No. & $\%$ & \\
\hline Sex & & & & & 0.550 \\
\hline Male & 34 & 51.5 & 32 & 48.5 & \\
\hline Female & 32 & 46.4 & 37 & 53.6 & \\
\hline Age (years) & & & & & 0.004 \\
\hline $26-35$ & 30 & 40.5 & 44 & 59.5 & \\
\hline $36-45$ & 14 & 42.4 & 19 & 57.6 & \\
\hline $46-55$ & 18 & 75.0 & 6 & 25.0 & \\
\hline$\geq 56$ & 4 & 100.0 & 0 & 0.0 & \\
\hline Education $^{2}$ & & & & & 0.001 \\
\hline Degree & 63 & 86.3 & 10 & 13.7 & \\
\hline Diploma & 3 & 4.8 & 59 & 95.2 & \\
\hline Profession & & & & & 0.001 \\
\hline Doctor & 59 & 84.3 & 11 & 15.7 & \\
\hline Other professions ${ }^{3}$ & 7 & 10.8 & 58 & 89.2 & \\
\hline Total & 66 & 48.9 & 69 & 51.1 & \\
\hline
\end{tabular}

${ }^{1}$ Good attitudes: respondent score $\geq 6$ out of 10 questions; poor attitudes: respondent score < 6 out of 10.

${ }^{2}$ Degree: respondents working in PHC with 3-4 years of tertiary education; Diploma: respondents working in PHC with 1-2 years post high-school education. ${ }^{3}$ Other professions were: nurses, laboratory technicians and primary health care (PHC) managers. 


\begin{tabular}{|c|c|c|c|c|c|}
\hline \multirow{2}{*}{ Demographic characteristic } & \multicolumn{2}{|c|}{ Good practices ${ }^{1}$} & \multicolumn{2}{|c|}{ Poor practices $^{1}$} & \multirow[t]{2}{*}{$P$-value } \\
\hline & No. & $\%$ & No. & $\%$ & \\
\hline Sex & & & & & 0.440 \\
\hline Male & 35 & 53.0 & 31 & 47.0 & \\
\hline Female & 32 & 46.4 & 37 & 53.6 & \\
\hline Age (years) & & & & & 0.013 \\
\hline $26-35$ & 30 & 40.5 & 44 & 59.5 & \\
\hline $36-45$ & 16 & 48.5 & 17 & 51.5 & \\
\hline $46-55$ & 17 & 70.8 & 7 & 29.2 & \\
\hline$\geq 56$ & 4 & 100.0 & 0 & 0.0 & \\
\hline Education $^{2}$ & & & & & 0.001 \\
\hline Degree & 64 & 87.7 & 9 & 12.3 & \\
\hline Diploma & 3 & 4.8 & 59 & 95.2 & \\
\hline Profession & & & & & 0.001 \\
\hline Doctor & 61 & 87.1 & 9 & 12.9 & \\
\hline Other professions ${ }^{3}$ & 6 & 9.2 & 59 & 90.8 & \\
\hline Total & 67 & 49.6 & 68 & 50.4 & \\
\hline
\end{tabular}

${ }^{1}$ Good practices: respondent score $\geq 6$ out of 10; poor practices: respondent score $<6$ out of 10 . ${ }^{2}$ Degree: respondents working in PHC with 3-4 years of tertiary education; Diploma: respondents working in PHC with 1-2 years post high-school education.

${ }^{3}$ Other professions were: nurses, laboratory technicians and primary health care (PHC) managers.

Overall, $49.6 \%$ of the respondents were categorized as having good practices about biomedical waste management. The mean (standard deviation) score for overall practice was $3.82(0.50)$.

There were statistically significant differences between those with good compared with poor practices related to biomedical waste management according to profession, education and age $(P<0.001,<0.001$ and 0.013 respectively). The results showed that $87.1 \%$ of the doctors had good attitudes towards biomedical waste management compared with only $9.2 \%$ of the other professions (nurses, PHC managers and laboratory technicians); $87.7 \%$ of those with a degree had good practices compared with only $4.8 \%$ of those with a diploma; and over $70 \%$ of professionals aged 46 years and older had good practices compared with less than $50 \%$ of those under 46 years. There was no statistically significant difference in good practices, according to sex.
There was a strong correlation between knowledge and attitudes, knowledge and practices, and attitudes and practices $(r=0.769,0.723$ and 0.837 respectively, $P<0.05)$.

\section{Discussion}

The results of our study show that there were highly significant differences in overall knowledge, attitudes and practices of the respondents in relation to their educational level and profession.

A study conducted in Lucknow in India found that a greater proportion of doctors had high knowledge levels and positive attitudes towards biomedical waste management than nurses (5). A study in Nainital, India concluded that for effective implementation of biomedical waste management practices every hospital needed mandatory periodic sensitization and continuous training programmes, especially focusing on the paramedical staff (6). A study undertaken using the Kayakalp assessment tool found that poor knowledge on segregation and collection of waste put at risk all health professionals as well as the patients visiting the hospital for treatment. This study concluded that unsafe disposal or improper disposal could adversely affect the community and environment (7).

We found that there was a positive correlation between knowledge and attitudes, knowledge and practices, and attitudes and practices. Training plays important role in enhancing knowledge of professionals dealing with biomedical and this will help to improve attitudes towards biomedical waste and in turn will result the best biomedical waste practices in the PHCs.

Although this study had a limited sample size, we believe it provides useful information on the KAP regarding biomedical waste practices among professionals in PHCs in Hail City. Our results suggest that there is a need for training for all PHC staff on biomedical waste not just the people who are dealing with biomedical; waste.

\section{Conclusion}

There is a need for frequent training programmes in all PHCs for all staff about biomedical waste management.

The Saudi Arabian Ministry of Health should develop a separate biomedical waste manual exclusively for the country which includes biomedical waste policies and procedures for hospitals and PHCs.

Funding: This study was funded by King Abdulaziz City for Science and Technology (KACST), Kingdom of Saudi Arabia (Grant number: LGP35-93).

Competing interests: None declared. 


\section{References}

1. Sharma A, Sharma V, Sharma S, Singh P. Awareness of biomedical waste management among health care personnel in jaipur, India. Oral Health Dent. Manag. 2013;12(1):32-40.

2. Chudasama R, Rangoonwala M, Sheth A, Misra SKC, Kadri AM, Patel UV. Biomedical waste management: a study of knowledge, attitude and practice among health care personnel at tertiary care hospital in Rajkot. J. Res. Med. Dent. Sci. 2017; 1:17-22.

3. Gupta S, Boojh R, Mishra A, Chandra H. Rules and management of biomedical waste at Vivekananda Polyclinic: A case study. Waste Manag. 2009;29:812-9.

4. Malini A, Eshwar B. Knowledge, attitude and practice of biomedical waste management among health care personnel in a tertiary care hospital in Puducherry. Int. J. Biomed. Res. 2015:6:172-6.
5. Sachan R, Patel ML, Nischal A. Assessment of the knowledge, attitude and practices regarding biomedical waste management amongst the medical and paramedical staff in tertiary health care centre. Int. J. Sci. Res. Publ. 2012;2(7):1-6.

6. Kumar M, Singh RK, Varshney U, Rawat V. Awareness and practices about biomedical waste among health care workers in tertiary care hospital of Haldwani, Nainital. National J. Med. Res. 2015;5(1):47- 51 (http://njmr.in/uploads/5-1_47-51.pdf, accessed 11 May 2017).

7. Somaiah, P.T., Shivaraj, B.M., 2016. A Study on Bio-Medical Waste Management Using Kayakalp Tool at District Hospital in Southern India. Natl. J. Community Med. 7, 614-617. 